\title{
Dysfunctional Families: One Central Theme in Two Fictional Works of Tony Morrison, Song of Solomon and Sula
}

\author{
Familias Disfuncionales: Un Tema Central en Dos \\ Novelas de Toni Morrison, Canción de Salomón y Sula
}

Luís Fernando Gómez R.

Abstract

Toni Morrison, Nobel Prize winner (1993), has been recognized as one of the most prominent novelists in the USA today. Her novels Song of Solomon and Sula rank enormous and original literary creativity through which she shows what it means to survive as an individual in the black families of America. Hence, this article explores the desperation and vulnerabilities of children who grow up in dysfunctional families and how they experience trauma and pain from their parents' unconventional actions and behaviors. The article accounts of the irregular experiences that the main characters of these two novels have to confront at hostile homes as they grow up changed, different from other children, and lack the essential educational guidance that prepare them for adulthood. Children are forced to assume unnatural roles within their families and, consequently, become dysfunctional members of society.

Key words:

Dysfunctional families, domestic violence, personality disorder, abnormal behavior, traumatic experience, marginalized childhood, symbolic decapitation.

En la actualidad, Toni Morrison, ganadora del premio Nóbel (1993), ha sido reconocida como una de las novelistas más prominentes de los Estados Unidos. Sus novelas Canción de Salomón y Sula gozan de poseer una enorme creatividad literaria a través de la cual presenta lo que significa sobrevivir como un miembro de las familias de raza negra en Norteamérica. Por ello, este artículo explora las vulnerabilidades de niños que crecen dentro de familias disfuncionales y de cómo sufren afectivamente a causa de las acciones y comportamientos poco convencionales de sus padres. El artículo discute las experiencias irregulares que los personajes principales de estas dos novelas tienen que enfrentar en hogares hostiles a medida que crecen diferentes a otros niños, carentes de la orientación educativa esencial que los prepare para la vida adulta. Los menores de edad son obligados a asumir roles anormales dentro de sus familias y en consecuencia se convierten en miembros disfuncionales de la sociedad.

\section{Palabras clave:}

Familia disfuncional, violencia intrafamiliar, problemas de personalidad, comportamiento anormal, experiencia traumática, niñez marginada, decapitación simbólica. 
Family dysfunctionality is certainly one of the main serious subjects that Toni Morrison develops in her novels Song of Solomon and Sula. Regarding Song of Solomon, all of the characters of the Dead family, including the parents, Macon and Ruth, and their children, are strongly marked by the consequences of domestic violence and personal conflicts which make them find it difficult to adjust to their own home and, therefore, to establish a good relationship with the outside world. Because of this tense dysfunctional disposition, the Dead family members become alienated and lack the ability to establish regular communication with others. It is certain that mischievous behaviors and a rushed abuse continually take place in this family due to problems such as compulsory violence, disrespect, mentally personal disorders, and the denial to recognize individually wrong conducts that the characters have had in their tormented lives. Incredibly, as can be observed in many instances of the novel, Milkman, the main character, and his sisters have grown up in this family with the idea that those problems are a normal process of life. Accordingly, this idea is a dysfunctional conception of their lives.

Macon Dead and Ruth Foster are dysfunctional parents precisely because they come from dysfunctional families as well. Macon comes from an abnormal family whose mother died when she was giving birth to her daughter Pilate. Thus, Macon, being just a young boy, had to assume the responsibility of the mother figure in order to take care of her little sister at the same time that he had to work with his father in the fields. Macon says, "I worked alongside my father . . . Our mother was dead. Died when Pilate was born. Pilate was just a baby. She stayed over at another farm in the daytime. I carried her over there myself in my arms every morning" (51). In the meanwhile, Macon's father used to spend the whole time working in the field and had no time to invest on the education of his two chil- dren. What is more, Macon's family eventually became a victim of social violence and racism in the hostile south of the USA. His father is murdered, his farm stolen, and Macon and his sister are forced to escape far away to save their lives. Macon never really had the opportunity to experience what a happy home, comfort, and luxury meant. As being a victim of violence and abuse in his childhood, Macon, who has a family now, is not competent to be a model father. Indeed, he has become a resented person up to the point that he detests his own sister Pilate. He thinks she is "not good. She is a snake, and can charm you like a snake" (54). He also hates his own wife and is distant from his son Milkman and his daughters.

One of the striking characteristic of Macon's dysfunctional role as a husband is his brutal violence to his wife. In his article, "Anaconda Love': Parental Enmeshment in Toni Morrison's Song of Solomon" Gary Storhoff notes that "the Dead family is organized by brutality and violence, most notably Macon Dead's wife-beating and his abuse of his children" (2). For instance, -having in mind that Ruth is a Methodist- one of the despicable moments of violence takes place when Ruth tells her family about the misunderstanding she had at the moment of the communion in a Catholic wedding that she was invited to. Rudely, Macon asks her, "'You didn't know that only Catholics take communion in a Catholic church?' his tone making it clear that he didn't believe her. . . Y You're a silly woman." Ruth answers, "Mrs. Djvorak didn't think so," and Macon replies, "She was just trying to keep the wedding going, keeping you from fucking it up." (67). As he continues arguing, Macon uses obscene verbal language against his wife as when he says, "You by yourself ain't nobody. You your daddy's daughter!" until, possessed by an outrageous impulse of range, he smashes her jaw. Dysfunctional husbands are generally men that not only ridicule and have a lack of empathy 
for their wives, but use threat and application of physical violence as the primary means of control over their wives. That is why the Dead family is abruptly controlled by Macon's abusive patriarchal authority who, after all, has a family only to satisfy his personal interests and goals.

Macon is also dysfunctional in his difficulty to express love and affection. He is more concerned about accumulating property and income than about the emotional state of his children. He is a materialist person, a man who only thinks in possessing money and things. He married Ruth, not because of love, but because he wanted to possess her father's fortune and become respected and admired by others. Ruth's testimony reveals what kind of man Macon is when she says, "He killed my father ... he threw my father's medicine away. . . He threatened to kill me. . I guess my father's money was more important to him than the satisfaction of killing me" (124-125). His wife is just another possession that gives him status and class. He is so obsessed by possessing everything -including people- that he has forgotten to provide love to his children. For him, his three children are another material acquisition. For instance, he recurrently tries to convince his son Milkman about the importance of money, "Let me tell you right now the one important thing you'll ever need to know: Own things. And let the things you own own other things. Then you'll own yourself and other people too" (55). In fact, Macon owns Milkman, his own son, to help him in his office with the accounting. Macon also greedily manipulates Milkman in order to convince him to go to the south to find the gold of the family that they left buried when they had to run away to save their lives from racist persecution. Macon uses people as a way to have more possessions: "He turned to his son full face and licked his lips. 'Macon, get it and you can have half of it; go wherever you want. Get it for both of us. Please, get it son. Get the gold!"' (172). This materialistic vision is one of the causes of his family decomposition. Macon only thinks to share the gold with his son Milkman because his ambition stops him from sharing it with any other member of his family. Hence, the basis of his bond to his family is just money. Love is not something that exists in his system of values. The major conflict with this type of dysfunctional parents is that they are not able to recognize their mistakes and, as a result, cause a total family chaos. As Wayne Matthews argues in his article "Dysfunctional Families: The Problem behind the Problem," "dysfunctional families are shame-based systems characterized by chaos, inconsistency, and unpredictability. They live in denial of their problems, and they lack emotional support from their members" (3). Unquestionably, the Dead family has a tense relationships due to the father's violent behavior and materialistic ambition since he would do what least expected to get what he craves, even to sacrifice his own family. He is convinced that as he has obtained things in life by means of inflicting violence, his domestic authority makes him an ideal father, but the facts show that he is a totally dysfunctional model.

Ruth, the mother of the Dead family, is also a dysfunctional individual. As Gary Storhoff also claims in his essay “'Anaconda Love': Parental Enmeshment in Toni Morrison's Song of Solomon," that "understanding the web of family dysfunctionality increases an appreciation of each character's complexity and of the novels ambitious thematic design," (2) Ruth is a character worth mentioning to demonstrate how she is a victim of a personality disorder unable to function as a conventional mother and as a lovely wife. Coming from a dysfunctional family as her husband, she is a motherless girl victim of her father's greed and pervert dominance. The novel reveals that she seems to suffer from Electra complex. So, once being married; she prefers to devote most of her time to her father by professing him an ill-fixated love than provi- 
ding marital love to her husband. In one of the conversations in the novel, Ruth's husband tells Milkman, his son, that he found Ruth the day of her father's death "lying next to him. Naked as a yard dog, kissing him, and she had his fingers in her mouth" (73). Whether Macon's testimony is true or not, it is evident that Ruth was emotionally dependent on the unique affection that her father provided her and, for this reason, it was difficult for her to start loving someone else like her husband. Ruth confirms her own emotional problem in her confession to her son Milkman at the cemetery where her father is buried. She recognizes that she was a girl suffering from isolation: "I lived in a great big house that pressed me into a small package. I had no friends . . but I didn't think I'd never need a friend because I had him (her father). I was small, but he was big. The only person who ever really cared whether I lived or died" (124). These words reveal not only her abnormal emotional dependence on her father, but the pathological instability of her emotional life because, once her father dies, she becomes even more alienated and unprotected. An evidence of this is that her husband never dares to love her again from the moment he is aware of her personality disorder. Tormented by these conflicts, she is never emotionally prepared to assume a marital life and to provide emotional balance to her children.

Loneliness is indeed one severe symptom of dysfunctional individuals even though they share the same house with other family members. In Ruth's case, once her father passes away, from whom she received care and love; she starts to develop extreme lovelessness. Her husband is the only candidate that can fill her emotional emptiness, but unfortunately, he abhors her. She says, "He did move into another room and that's the way things stayed until I couldn't stand anymore" (125). By means of Pilate's witchcraft who prepared a potion, Ruth manages to gain her husband's affection back until, as she explains, "he came in the middle of the day to be with me ... Two months later I was pregnant” (125). This dysfunctional behavior of recurring to the use of witchcraft to obtain love suggests that her necessity to stay with somebody is not so much the result of authentic love for her husband, but an expression of despair to satisfy her pathological problem of loneliness and emotional dependence. This also suggests how members of a dysfunctional family are controlled by bizarre compulsions to get away with their obsessive needs.

As can be seen, Ruth's pregnancy takes place in a hostile environment and under odd circumstances. The baby she expects, Milkman, is not the product of a regular marital relationship based on values of love and commitment. We can clearly observe that when Macon knows that he has been spelled by the voodoo magic practices of both his sister Pilate and his wife, he coerces Ruth to abort the baby by forcing her to drink a strange potion. Ruth confesses her son that "I know he never told you that he killed my father and that he tried to kill you" (124). The birth of Milkman is tragically the result of an abruptly dysfunctional relationship set within extremely domestic violence since this baby was never planned to be brought to life under his parents' mutual agreement. In view of that, Milkman, the new son, also becomes a dysfunctional individual.

In her book Domestic Violence: The Criminal Justice Response, Eve Buzawa affirms that "Children in abusive families appear to be the more susceptible to the impact of domestic violence. . . Exposure to family violence apparently is associated with the development of positive feelings towards using violence to 'solve' problems and hence indirectly to violent offending" (23-26). This assertion can be applied to Milkman's dysfunctional behavior. He has been so exposed to the domestic violence of her parents that he equally behaves under a cruel and aggressive conduct. Every time Milkman has to solve a problem, he regularly destroys people's feelings because he 
responds with violence to stop others' violence. One particular instance of his dysfunctional misbehavior is in the scene when Macon beats his wife because she made a mistake at a Catholic wedding and because she happily remembers that she was "her daddy's daughter" (67). By imitating the actions of his own father, Milkman responds with the same violent reaction and knocks his father into the radiator. Even more, he threatens his own father by telling him, "You touch her again, one more time, and I'll kill you" (67). This scene shows one of the most common conflicts in dysfunctional families which is parents' attempt to involve children in their feuds so that they children become their defenders. Children are forced to take sides in conflicts between parents up to the point that there are verbal threats and physical abuse between parents and sons. Because of this, children are lost and frustrated with their family life.

Being a dysfunctional son, Milkman is not an emotionally and socially stable boy. Like his father, he is self-centered and materialistic and lacks the feelings to love his parents genuinely: "Milkman feared his father, respected him" but "he differed from him as much as he dared" (63). He equally is reluctant to communicate with his mother because he thinks she nursed him until he was four yeas old, something that he finds abnormal. Since he cannot establish a meaningful connection with his parents, he is an isolated and excluded individual. The alienation from his family is remarked when he goes to visit her aunt Pilate for the first time and discovers that being there with others "was the first time in his life that he remembered being completely happy" (47). On the contrary, there is no happiness when he is at home because there he is unable to sympathize with his pathetic parents.

What is even more striking in the novel is that Milkman, being already 31 years old, has no idea of what he wants to do with his life. Yet, he wants to escape from home. In a conversation with his father, Milkman says, "I have to get away just the same. I'm not leaving the country; I just want to be on my own. Get a job on my own, live on my own" (163). He is also interested in finding the lost gold of his father so that he can get part of it and settle down independently and happily. In the end, desperate by the many unsolved problems at home, Milkman finally decides to go away from the dysfunctional conflicts of his family in order to find his own destiny. Eventually, he is able to discover the past heritage of his family as he learns in his journey that material possessions such as gold are not as important as the knowledge of his family identity. Milkman has to run away from home to find himself and to be able to understand his family. Only by leaving home, he is able to fix the mark of domestic violence inflicted by his parents. He equally realizes that his family life has blotted him with a personality characterized by abnormal features that has alienated him to grow in an environment of strong values and safety. Gary Storhoff notes that "Ruth and Macon have damaged their children, but Milkman must learn to understand their past and forgive their parental transgressions" (11). Tony Morrison depicts in Song of Solomon the crude reality of many families that are victims of domestic violence. She denounces the dangers of compulsive and obsessive behaviors of parents that disturb the balance of family harmony and affect the normal development of the personality of their children. The presence of compulsive behaviors, personal disorders, and miscommunication are the syndrome of dysfunctionality. Unluckily, the Dead family is a dysfunctional family that is never able to provide the means to solve their conflicts. Subsequently, their lives are ineffective and unbearable. Macon, Ruth, her son Milkman, and even their two daughters are victims of one of the most frightening experiences of the social system called domestic violence which is not regularly recognized as a problem deserving public attention. 
In relation to the novel Sula, we can also encounter its main character, Sula, as another dysfunctional figure. In a broad sense, the black people of Bottom town, the place where she was born, believe that Sula is the personification of evil. Most of them call Sula a "witch," a "pariah," and a "bitch," and blame her for the many misfortunes in and outside her family. Through the novel, Sula is believed to be a woman that causes the destruction of several people who live with her. Among several calamitous events worth mentioning, she causes the death of the innocent boy Chicken Little, and incredibly, she does not do any action to save her own mother from the flames the day her mamma was horribly burnt by a fire at home. Indeed, Sula was "standing on the back porch just looking" and "watched Hannah (her mother) burn not because she, Sula, was paralyzed, but because she was interested" (78). That is to say, Sula was somehow fascinated by seeing how her mother painfully died by a horrible conflagration. This event offers traits to understand the serious level of dysfunction that Sula experiences. Furthermore, Sula has sexual encounters not only with her best friend's husband and with the men of the Bottom town, but "Sula slept with white men" (112), causing this "chocking disgust" (113) among the people of her black community. Sula is considered such a dangerous woman in her town that "they laid broomsticks across their doors at night and sprinkled salt on porch steps. But aside from one or two unsuccessful efforts to collect the dust from her footsteps, they did nothing to harm her. As always the black people looked at evil stony-eyed and let it run" (113). In addition, Sula's own death at the end of the novel provokes a frost ruining harvests, bringing "scarlet fever ... rheumatism, pleurisy, earaches, and a world of other ailments" (153). The chain of all these incidents, at a first sight, shows Sula as a malevolent woman that was born to trace disgrace to the world and hurt everybody around her. However, in a deep sense, the novel highly suggests that she is not only such a horrible devastating force that destroys what is on her way, but becomes a dysfunctional woman who is victimized and "decapitated" by both the chauvinist power of males and the submissive role of women in her society.

By approaching a turning point in the characterization of this wicked woman in terms of her dysfunctional behavior, we can appreciate how Sula's female identity is symbolically headed off. To see how she is maltreated by the oppressive boundaries of her community, the thematic notion of female decapitation proposed by Carlyle Thomson in her essay "Circles and Circles of Sorrow' Decapitation in Tony Morrison's Sula" will be implemented here. Although Thompson mainly examines in her essay the metaphorical notion of decapitation at different levels of interpretation, suggesting that Toni Morrison reveals how the black race has been socially, economically, racially, and interpersonally discriminated and "decapitated" in America, the notion of figurative decapitation can also help us to elucidate how Sula is definitely a dysfunctional character that perpetrates the most licentious actions against the members of her family and the people of her community at Bottom. Thomson states that "female decapitation becomes an equal opportunity process where men with a taxonomic gaze can decapitate women and where women who internalize patriarchal hegemony can decapitate other women and simultaneously decapitate themselves" (140). This metaphorical idea of female decapitation implies how members of the same gender can cause destructive and detrimental damage to each other. In the novel, Sula is primarily decapitated by the harsh attitudes of both male and female figures of her town and, at the same time, by her own. Once her life is damaged and decapitated, Sula suffers from a notoriously dysfunctional personality.

Sula is an alienated being due to the fact that she is the daughter of a dysfunctional family. We 
are aware that Sula is traumatized by the weird misbehavior and carelessness of her own mother, Hannah. We can see in the novel that Sula's father died when she was three years old, and ever since, her mother gave herself to the practice of an indecent and unmoral life. Toni Morrison points out in this novel that Hannah "simply refused to live without the attentions of a man. So after the death of her husband Rekus, Hannah starts to hold a steady sequence of lovers, mostly the husbands of her friends and neighbors. Her flirting was sweet, low and guideless, and ... She rippled with sex" (42). Hanna ignores Sula and prefers to enjoy an unrestrained sexual activity with different men. In this sense, Sula's mother lacks a strongly moral code to educate Sula appropriately. In turn, Sula grows up lacking empathy towards her mother with the understanding that such a feeling is normal. Undoubtedly, the licentious behavior of her mother causes Sula's dysfunctional personality. Toni Morrison narrates that one day "Sula came home from school and found her mother in the bed, curled spoon in the arms of a man" (44). Obviously, Sula, being a child, discovers that her mother is an immoral and promiscuous woman who metaphorically decapitates the stability of others' marriages and the moral stability of her own daughter. Toni Morrison remarks that Hannah "could break up a marriage before it had even become one" (44). As a result, Hannah decapitates her daughter's moral values to love a man genuinely.

In the long run, once Sula is a grown-up, she begins to behave like her mother, suffering from sexual compulsion, and starts to sleep with many men as well. In this respect, George A. Boyd argues in his article "When You Grow Up in a Dysfunctional Family" that the traumatized children that are raised in dysfunctional environments usually "feel inexplicably compelled to repeat the abuses that were done to them" (1). From this perspective, Sula follows her mother's sexual practices thinking that they are part of a normal adult's conduct and is even daring to have sex with Jude who is her best friend's husband. When Nel, Sula's dearest friend has the chance to confront Sula and asks "How come you did it, Sula?" Sula confesses Nel that she had slept with Jude not because of authentic love, but just because "there was a space and Jude filled it up. That's all. He just filled up the space" (144). In other words, Sula took advantage to have sex with Jude just because the opportunity was given. She only wanted to have the pleasure to be with another man who didn't mean too much to her. Sula's dysfunctional personality can be even more appreciated when $\mathrm{Nel}$ reminds her that they were very good friends, "We were friends. And you didn't love me enough to leave him alone. To let him love me. You had to take him way," and Sula carelessly replies, "What you mean take him away? I didn't kill him, I just fucked him. If we were very good friends, how come you couldn't get over it?" (145). Such an answer reveals the distortion of values originally accepted in Sula's dysfunctional family. Sula is portrayed having a behavioral disorder as she not only disrespects, and symbolically "decapitates" the marital relationship of her friend $\mathrm{Nel}$, but at the same time ruins her close relationship with her best friend. What is even more shocking is that Sula does not care if those who love her are affected by her irresponsible actions. In general, dysfunctional personalities are unable to recognize their faults. Instead, they usually recur to provide unfounded explanation for their wrongdoings. Thus, Toni Morrison clearly presents through this incident how female dysfunctionality is rudely performed among women through a vicious chain of sexual practice and dishonesty.

In the complexity of the notion of symbolic decapitation, Sula decapitates the marriage of her friend because, in turn, her friend $\mathrm{Nel}$ has also decapitated Sula's identity. Both girls were close together since the time they met in childhood. They were only children and "they were solitary 
little girls whose loneliness was so profound it intoxicated them" (51). As it happens in Song of Solomon, loneliness emerges as a sharply devastating force that attacks those characters that come from violent and oppressive homes. The unbearable experience of being solitary and being ignored by their paternal figures, makes Sula and Nel become dysfunctionally alienated beings. It is seen in the novel that from the first time they meet, both are in such a big need to establish a powerful bond of friendship that they feel "the ease and comfort of old friends" (52). Sula and Nel emotionally depend on one another in order to complement their lonesome lives. Even more, they start to develop such a reciprocated empathy, that they become faithful accomplices of their own felonies, as it happens when both promise not to tell anybody about their involvement in Little Chicken's death, being this a real test of authentic friendship.

Toni Morrison goes on describing their congenial amity as she also remarks that these two dysfunctional women were "daughters of distant mothers and incomprehensible fathers, they found in each other's eyes the intimacy they were looking for" (52). This fact emphasizes how both girls identify harmoniously. Unfortunately, once Sula learns that her best friend falls in love with Jude and marries him, she is not able to understand this normal event of life. In contrast, Sula, as being a dysfunctional person, thinks that Nel's marriage is a dangerous action since part of Sula's identity with $\mathrm{Nel}$ is symbolically decapitated by Nel's husband. In this respect, Thomson argues in her essay "Circles and Circles of Sorrow' Decapitation in Tony Morrison's Sula” that "decapitation represents any marginalizing process whereby and individual loses his or her identity, voice and subjectivity" (141). Once one part of Sula's identity is taken away by the obnoxious interference of Jude's presence, their friendship can never be the same and Sula will be incomplete. Frustrated and marginalized by the decapitation that her best friend has caused to their friendship and, presumably feeling again intoxicated by loneliness, Sula goes away from town for a period of ten years to later come back and decapitate her friends' marriage by having sex with Jude. Thus, Sula returns to revenge by inflicting violence on Nel, who paradoxically is her dearest friend.

To provide more evidences and understand in a deeper way why Sula ruins her friend's married life, we may go back in time when her dysfunctional mother, Hannah, was alive. In one occasion, Sula overhears when Hannah says that she loves her only daughter, but does not like her. This revelation seems to alienate Sula's identity even more. As Sula realizes that her mother is a promiscuous woman who likes to stay with different men, but dislikes her, Sula becomes a lost child and opts to spend lonely hours in the attic to evade the presence of her mother. She equally learns to disvalue the importance of marriage and family as normal institutions of life commitment. Since Sula is compelled to hold a solitary life lacking the care and protection of her mother, she seriously develops a severe isolation problem. All of these conflictive situations lead us to observe that a lost and alienated child:

"is characterized by shyness, solitariness, and isolation. Inwardly, he or she feels like an outsider in the family, ignored by parents and siblings, and feels lonely. The Lost Child seeks the privacy of his or her own company to be away from the family chaos, and may have a rich fantasy life, into which he or she withdraws. The Lost Child often has poor communication skills, difficulties with intimacy and in forming relationships, and may have confusion or conflicts about his or her sexual identity and functioning." (Boyd, 2).

That is why, we may imply, that later when Sula sees her mother burning in flames, she does not have the initiative to save her. After all, Hannah has marginalized Sula, and Sula returns this courtesy. Ironically, Sula becomes evil and is 
accused by her grandmother of being "interested" in the consummation of her mother's body. This action contains a decapitating effect in the life of her mother. If we take into account that Sula is capable of doing this to her own mother, we may have for granted that she is also able to destroy her friend's marriage without any remorse because in her childhood Sula not only learned that marriage is not a serious compromise, but that men stole her mother's love. Sula's dysfunctionality relies in the fact that marriage, men, and sex are opposite forces against women's happiness and freedom. It is a misfortune that again in her life, Sula has to live this experience with her best friend once Nel's love is taken by a man and puts an end to the friendly "intimacy" they had found "in each other's eyes" (52).

The rapacious determination that Sula takes to make Nel pay for the destruction of their friendship, shows her once more as an evil and dysfunctional character. However, we need to understand that Sula is also decapitated by her best friend. Sula's hurt feelings are clearly exposed when she ponders "Now Nel belonged to the town and all of its ways. She had given herself over to them. It had surprised her a little and saddened her a good deal when Nel behaved the way the others would have" (120). Sula and Nel decapitate each other causing violence and selfdestruction. Sula's self-decapitation is portrayed in her rebellious attempt to be liberated from the conventions of the black community she belongs to such as having a husband, raising children, and mainly being dominated by a male figure. At the end of the novel, when Nel tries to convince her friend Sula that women cannot be released from the social standards imposed by her community, Nel claims, "you can't act like a man. You can't be walking around all independent-like, doing whatever you like, taking what you want, leaving what you don't" (142). As a matter of facts, Sula has gone against all the established conventions and has reacted against the repressive margins of her society that ironically has provoked her dysfunctional behavior and her self-mutilation. Sula has grown up being different from others and has never adapted to the hypocritically social rules of her community because those rules alienated her since she was a child. This situation causes Sula to die in complete isolation being considered not only a witch and a pariah, but a bad omen that always brought ruin and destruction to others. Consequently, she not only destroys others' lives. She is also victimized.

As can be seen, the idea of Sula's dysfunctional characterization is examined through the concept of symbolic decapitation, a concept that is understood as the brutal act of hurting the people she is supposed to love. Sula is depicted not only as the evil decapitator of her mother, her best friend, and her town. She is also a decapitated woman whose identity and liberal ideas of independence are beheaded by the hegemony of the family and the society she has to live in. Sula is irrefutably evil, but she is also the victim of human evil itself. In conclusion, Decapitation is the mutually dysfunctional result of both herself and the ones who coexist with her. She is not the only one to blame.

Toni Morrison treats in Song of Solomon and Sula the experience of innocent children who have to grow up in families where they become victims of pathological issues such as abuse, domestic violence and marginalization. They have to suffer psychologically from depression and anxiety, and hysterical attitudes. They usually have abnormal behaviors including their will to run away from their families, fall in prostitution and promiscuity; and interpersonally, they have difficulty trusting people. Beyond that, they hurt and destroy those around them. Macon, Ruth, Milkman and Sula become aggressive and desperate adults who dare to do unacceptable and unthinkable actions in order to survive. They think that whatever action they do; no matter if it is good or bad, is a normal behavior of their 
personal development. After all, they follow the example that they were given at home. It is important to reiterate that the conflicts that take place in dysfunctional families generally remain unsolved in the privacy of the family and then their members usually feel unhappy, alienated, and excluded for the rest of their lives. Toni Mo- rrison portrays vividly this reality in her novels to let us see the evils that are part of our own families. Morrison has given us a scary warning of the dysfunctional human beings that are growing up in our families, and how they are current members of our contemporary society. 기

\section{References}

BUZAWA, Eve (2003) Domestic Violence: The Criminal Justice Response. SAGE Publications. California.

BOYD, A. George (1992). When You Grow Up in a Dysfunctional Family. Electronic publication: http:// www.mudrashram.com/dysfunctionalfamily2.html

MATTHEWS, Wayne (1993). "Dysfunctional Families: The Problem behind the Problem." North Carolina Cooperative Extension Service. North Carolina State University. Electronic publication number FCS4104.

STORHOFF, Gary (1997). “Anaconda Love’: Parental Enmeshment in Toni Morrison's Song of Solomon" in Style, summer, Vol. 31, issue 2.
THOMPSON, Carlyle (2003). "Circles and Circles of Sorrow:' Decapitation in Tony Morrison's Sula” in CLA Journal. A Quarterly Official Publication of the College Language Association. Vol. XLVII, No. 2.

WAUGH, Patricia (2006) Literary Theory and Criticism. An Oxford Guide. Oxford University Press.

On line: Understanding Dysfunctional Relationship Patterns in Your Family

http://www.couns.uiuc.edu/brochures/dysfunct. htmhttp://www.couns.uiuc.edu/ brochures/dysfunct.htm 